\title{
Don't let May trample on the NHS
}

\author{
Fiona Godlee editor in chief
}

The BMJ

News that Theresa May will feature in US Vogue magazine has added to what Martin McKee calls "the uncomfortable disconnect between her words and actions" (doi:10.1136/bmj. j213). Her homily on the steps of 10 Downing Street six months ago, including sentiments that she repeated in a speech last week, suggests deep concern about people who are struggling to get by-the "just about managing." Her actions as home secretary and now as prime minister give no such comfort.

The United Kingdom is one of the most unequal societies in the developed world (www.bbc.co.uk/news/business-37341095), and despite it also being one of the world's richest countries, its health spending is below the European average, and its health and social care system is near to collapse. Both McKee and Chris Ham in his editorial (doi:10.1136/bmj.j218) point out that governments in which May has served have either contributed to this sorry state or repeatedly failed to tackle the underlying causes.

The result, unflinchingly documented by the BBC's fly on the wall documentary Hospital, is senior surgeons and their teams standing idle (doi:10.1136/bmj.j281) and their seriously ill patients sent home because of a lack of intensive care beds, while inadequate social care means that medically recovered patients are stuck in hospital. Outside hospitals GPs are struggling to get patients admitted, patients wait in ambulances parked outside casualty, and, for the first time in several years, waiting lists are growing and even cancer treatments are being delayed.
May's response has been deplorable, justifying the horror expressed in BMA chairman Mark Porter's letter to her (doi:10. 1136/bmj.j296). She has, he says, downplayed the crisis in the NHS in England and deliberately scapegoated GPs (doi:10.1136/ bmj.j259) to distract from what's happening in the NHS. She has also picked a damaging fight with Simon Stevens, who as NHS England's chief executive understands how the NHS works and what it needs to move forward and is one of the few in the NHS who has "spoken truth unto power," as David Lock describes (doi:10.1136/bmj.j256).

As Margaret McCartney says in her column this week, May's intervention represents "the kind of policy making that's serially disastrous for the NHS" (doi:10.1136/bmj.j246). Such knee jerk political interference, without reference to even the most superficial evidence, causes harm and waste and further demoralises the professionals on whom the service depends.

Yes, there are things clinicians and managers can and should be doing to eliminate unwarranted variation and improve the quality of care. Gareth Iacobucci describes many of these in his latest article (doi:10.1136/bmj.j204), and Jennifer Dixon calls for clinicians to find ways to work better, not harder (doi:10. 1136/bmj.j216). But this doesn't let the government off the hook. The UK needs a proper financial settlement for its health and social care, one that reflects its wealth and its claims to be a just and socially progressive society. 